\title{
Synthesis and colour properties of blue-violet cassiterite pigments doped by terbium ions
}

\section{Lucie Karolová, Žaneta Dohnalová, Jakub Trojan}

Department of Inorganic Technology, Faculty of Chemical Technology, University of Pardubice, Studentská 573, 53210 Pardubice, Czech Republic, e-mail: lucie.karolova@student.upce.cz

\begin{abstract}
This research was focused on the preparation of mixed metal oxide pigments doped with terbium ions with the general formula of $\mathrm{Sn}_{0.752} \mathrm{Co}_{0.08} \mathrm{P}_{0.16} \mathrm{~Tb}_{0.008} \mathrm{O}_{2}$. These pigments were synthesised by solid state reactions at high calcination temperatures. The temperature range was chosen from 1350 to $1500{ }^{\circ} \mathrm{C}$. The goal was to develop conditions for the synthesis of this type of pigments and to determine the influence of terbium ions on the colour properties of these compounds. All prepared pigments were applied into the organic matrix and into the ceramic glaze. Thermal behaviours of the reaction mixtures were investigated using differential thermal and thermogravimetric analysis. Synthesised $\mathrm{Sn}_{0.752} \mathrm{Co}_{0.08} \mathrm{P}_{0.16} \mathrm{~Tb}_{0.008} \mathrm{O}_{2}$ pigments were compared with concurrently prepared pigment $\mathrm{Sn}_{0.760} \mathrm{Co}_{0.08} \mathrm{P}_{0.16} \mathrm{O}_{2}$ depending on the calcination temperature with respect to the colour properties in CIE $L * a * b *$ colour space, furthermore from the point of particle size distribution and phase composition. All compounds provided blue-violet hues that are stable in ceramic glazes.
\end{abstract}

\section{Acknowledgements}

The authors would like to thank for the financial IGA University of Pardubice (SGSFChT_2017_007).

\section{Keywords:}

Solid state reaction, colour properties, thermal properties, cassiterite

\section{Introduction}

Ceramic pigments are inorganic chemical compounds, which provide colour and they are insoluble in a medium, with which they do not interact physically or chemically. They are characterised by high thermal and chemical stability. Structures of ceramic pigments contain chromophore ions, which impart colour to the originally colourless system [1]. All blue ceramic pigments known currently (except the vanadium-zirconium blue, CPMA 14-42-2) are based on doping of thermally stable crystal lattice by ions of cobalt [2-3]. The colour of cobalt pigments depends on their thermal stability, chemical reactivity towards the glaze components. For cobalt based pigments, Co (II) ions can be incorporated as colouring agents, where commonly they adopt a tetrahedral coordination, thought octahedral coordination is also possible. In this regard, an evaluation from octahedral $\left[\mathrm{Co}^{\mathrm{II}} \mathrm{O}_{6}\right]$ to the most stable tetrahedral $\left[\mathrm{Co}^{\mathrm{II}} \mathrm{O}_{4}\right]$ coordination has been observed with an increase in the alkalinity and also with the increase in the calcination temperature of the material [4-5].

Cassiterite pigments are based on tin dioxide respectively they are mixed oxides, where tin dioxide is the main component. Tin dioxide $\left(\mathrm{SnO}_{2}\right)$ is an $\mathrm{n}$-type semiconductor with tetragonal rutile structure that possesses superior properties, such as transparency, remarkable chemical and thermal stabilities [6]. It has been widely used as electrode materials, optoelectronic devices, gas sensors, catalysts and as colouring agents in the ceramic industry [7-11]. Cassiterite pigments contain crystal lattice of tin dioxide, which is suitable for doping by coloured admixtures (chromophores). By partial substitution of Sn (IV) ions $(0.069 \mathrm{~nm})$, the chromophore ions can be comparatively easy implemented into the crystal lattice of tin dioxide [12-14]. The advantage of cassiterite pigments is their easy preparation and great availability of raw materials [15]. These pigments are based on tin dioxide which crystallises in tetragonal structure to form bipyramidal crystals and which plays the dominant role in the final compound [16]. Tin dioxide is used as a host lattice for important ceramic pigments, e.g. Chrome Tin Orchid Cassiterite (CPMA No. 11-23-5), Tin Vanadium Yellow Cassiterite (CPMA No. 11-22-4) and Tin Antimony Grey Cassiterite (CPMA No. 11-24-8) [2, 17-19].

The solubility limit of $\mathrm{Co}$ (II) ions in $\mathrm{SnO}_{2}$ is up to $\mathrm{x}=0.08$ (for temperatures up to $1150{ }^{\circ} \mathrm{C}$ ). On the other hand, the solubility limit is just $\mathrm{x}=0.02$ at low temperature [20]. The presence of the second phase - cubic $\mathrm{Co}_{2} \mathrm{SnO}_{4}$ is usually observed when the solid solution limit is exceeded. Co (II) ions were reports as one of the most effective dopants for the densification of $\mathrm{SnO}_{2}$, because $\mathrm{Co}$ (II) ions behave as acceptors and create oxygen vacancies in the $\mathrm{SnO}_{2}$ lattice. The doping of Co (II) ions in $\mathrm{SnO}_{2}$ brought significant changes in the physical properties of the samples. Mehraj et al. observed that average crystallite size, lattice constant and porosity decreased with Co doping. The Co-doped samples are paramagnetic at room temperature [21-25]. 
In the present work, the synthesis of pigments with general formula $\mathrm{Sn}_{0.752} \mathrm{Co}_{0.08} \mathrm{P}_{0.16} \mathrm{~Tb}_{0.008} \mathrm{O}_{2}$ was studied. Because of Co ions have oxidation state lower than (IV), a second element with oxidation state higher than (IV) is always added in order to fulfill the electroneutrality of the structure. In this case are P (V) ions used as chargecompensating elements. The goal was to develop conditions (especially calcination temperature) for the synthesis of these pigments and to determine the influence of terbium ions on the colour properties of $\mathrm{Sn}_{0.752} \mathrm{Co}_{0.08} \mathrm{P}_{0.16} \mathrm{~Tb}_{0.008} \mathrm{O}_{2}$ pigments. Synthesised $\mathrm{Sn}_{0.752} \mathrm{Co}_{0.08} \mathrm{P}_{0.16} \mathrm{~Tb}_{0.008} \mathrm{O}_{2}$ compounds were compared with concurrently prepared pigments $\mathrm{Sn}_{0.760} \mathrm{Co}_{0.08} \mathrm{P}_{0.16} \mathrm{O}_{2}$ from the standpoint of their structure, colour properties and particle size distribution.

\section{Experimental}

Synthesis of cassiterite pigments

The starting raw materials used for preparation of $\mathrm{Sn}_{0.752} \mathrm{Co}_{0.08} \mathrm{P}_{0.16} \mathrm{~Tb}_{0.008} \mathrm{O}_{2}$ pigments were $\mathrm{SnO}_{2}(>99.9 \%$, Alfa Aesar, Germany), $\mathrm{Co}(\mathrm{OH})_{2}\left(98 \%\right.$, Shepherd Color Company, USA), $\mathrm{NH}_{4} \mathrm{H}_{2} \mathrm{PO}_{4}(99.5 \%$, Lachema a.s., Czech Republic) and $\mathrm{Tb}_{4} \mathrm{O}_{7}(99.9 \%$, Indian Rare Earths Ltd., India). Above mentioned compounds were weighed in the required stoichiometric amounts and then were homogenised in an agate mortar. The mixtures were calcinated in corundum crucibles in an electric resistance furnace. The heating of furnace was programmed with increasing temperature at a rate $10^{\circ} \mathrm{C} \cdot \mathrm{min}^{-1}$ and the calcination temperature of $1350-1500{ }^{\circ} \mathrm{C}$ was maintained for three hours. All samples were gradually cooled to room temperature and ground in an agate mortar.

Application of the pigments into organic matrix and ceramic glaze

The calcinated powder samples were applied into the organic matrix (dispersive acrylic paint Parketol, Balakom a.s., Czech Republic) in mass tone and into medium temperature ceramic glaze P 07491 (Glazura, s.r.o., Czech Republic), with the amount of a pigment sample $10 \mathrm{wt} \%$. For testing in the organic matrix, the suspension containing $1 \mathrm{~g}$ of the sample and $1.5 \mathrm{~cm}^{3}$ of the binder was homogenised. This suspension was converted by a pestle to dense paste able to flowing. Coloured coating films were prepared by application of the paste on white nonabsorbing glossy paper. The coating layer of film was created by dragging the Bird's applicator. Prepared coating films were kept to dry spontaneously in the open air. Then they were ready for an evaluation of colour properties of pigments in the organic matrix in mass tone. In the case of application in the ceramic glaze, an aqueous suspension containing $10 \mathrm{wt} \%$ of pigment and $90 \mathrm{wt} \%$ of transparent ceramic glaze with an appropriate amount of distilled water was prepared by hand-grinding. The suspension was applied by using the brush on unglazed ceramic tile and after drying in the air was glazed at $1050{ }^{\circ} \mathrm{C}$ for $15 \mathrm{~min}$.

\section{Simultaneous TG-DTA analysis}

The methods of thermal analysis can provide the first information about the temperature area of the formation of inorganic pigments. The formation of these pigments was followed by thermal analysis using STA 449C Jupiter (Netzsch, Germany) which allows the simultaneous registration of the thermoanalytical curves TG and DTA. The thermoanalyzer determines small changes in mass and thermal effects with high accuracy (weighing accuracy $10^{-8} \mathrm{~g}$; error in measuring thermal effects $1 \mathrm{mV}$ ). The starting raw materials $-\mathrm{SnO}_{2}, \mathrm{Co}(\mathrm{OH})_{2}, \mathrm{NH}_{4} \mathrm{H}_{2} \mathrm{PO}_{4}$ (or eventually $\mathrm{Tb}_{4} \mathrm{O}_{7}$ ) and the prepared starting mixtures were studied by thermal analysis in corundum crucible in the air in temperature area from 30 to $1400{ }^{\circ} \mathrm{C}$. The increase of temperature was $10{ }^{\circ} \mathrm{C} \mathrm{min}{ }^{-1} \cdot \alpha-\mathrm{Al}_{2} \mathrm{O}_{3}$ was used as reference material.

$\mathrm{XRD}$ analysis

The phase analysis of the powdered materials was studied by $\mathrm{X}$-ray diffraction analysis. The phase composition was determined using diffractometer MiniFlex 600 (Rigaku, JPN) equipped with a vertical goniometer of $15 \mathrm{~cm}$ in the $2 \Theta$ range of $10-80^{\circ}$. The accuracy of goniometer was $\pm 0.02^{\circ}$. X-ray tube with $\mathrm{Cu}$ anode $(\mathrm{U}=40$ $\mathrm{kV}, \mathrm{I}=15 \mathrm{~mA}$ ), secondary graphite monochromator, scintillation $\mathrm{NaI}(\mathrm{Tl})$ counter, and $\mathrm{X}$-ray of copper were used. Wavelength of the applied X-ray is $K_{\alpha 1}=0.15418 \mathrm{~nm}$ for angle $2 \Theta<35^{\circ}$ and $K_{\alpha 2}=0.15405 \mathrm{~nm}$ for angle $2 \Theta>35^{\circ}$.

Measurement of colour properties of applied cassiterite pigments

The colour properties of all final applications were objectively evaluated by measuring of spectral reflectance in the visible region of light (400-700 nm) by using a spectrophotometer ColorQuest XE (HunterLab, USA). Standard illuminant D65 was used as internationally recommended white daylight, measurement conditions were as follows: $10^{\circ}$ supplementary standard observer, measuring geometry $\mathrm{d} / 8^{\circ}$. The colour properties are 
described in terms of CIE $L^{*} a^{*} b^{*}$ system (1976). The value $a^{*}$ (the red-green axis) and $b^{*}$ (the yellow-blue axis) indicate the colour hue. The value $L^{*}$ represents the lightness or darkness of the colour as related to the natural grey scale. In the $L^{*} a * b^{*}$ system, it is described by numbers from 0 (black) to 100 (white). The value $C$ (Chroma) represents saturation of the colour and determines colour purity. The colour hue of pigments is also possible to express as a hue angle $H^{\circ}$. Hue angle $H^{\circ}$ is defined as starting at the $+a^{*}$ axis and indicates the position of the sample in $a^{*}, b^{*}$ diagram. It is expressed in degrees; $H^{\circ}=350-35^{\circ}$ (for red), $H^{\circ}=35-70^{\circ}$ (for orange), $H^{\circ}=70$ $105^{\circ}$ (for yellow), $H^{\circ}=105-195^{\circ}$ (for green), $H^{\circ}=195-285^{\circ}$ (for blue), $H^{\circ}=285-350^{\circ}$ (for violet). Chroma $C$ and hue angle $H^{\circ}$ of samples were calculated according to the Eqs. (1) and (2).

$C=\left(a^{* 2}+b^{* 2}\right)^{1 / 2}$

$H^{\circ}=\operatorname{arctg}\left(b^{*} / a^{*}\right)$

The total colour difference $\Delta E^{*}$ CIE in the CIE $L * a * b *$ diagram, which indicates the degree of colour difference between the two samples, is defined by the following equation (3), where $\Delta L^{*}, \Delta a^{*}, \Delta b^{*}$ are differences in $L^{*}, a^{*}$ and $b^{*}$ values between colour sample and colour of standard.

$\Delta E^{*}{ }_{C I E}=\left[\left(\Delta L^{*}\right)^{2}+\left(\Delta a^{*}\right)^{2}\left(\Delta b^{*}\right)^{2}\right]^{1 / 2}$

Measuring of particle size distribution

The particle size distribution of the synthesised pigments was measured using an equipment Mastersizer 2000/MU (Malvern Instruments, Ltd., UK). This device provides volumetric distribution and uses the laser diffraction on particles dispersed in a liquid medium. The particle size distribution was analysed by two lasers - red light (He-Ne laser with wavelength $633 \mathrm{~nm}$ ) and blue light (laser diode with wavelength $466 \mathrm{~nm}$ ). The pigments were ultrasonically homogenised in the solution of $\mathrm{Na}_{4} \mathrm{P}_{2} \mathrm{O}_{7}\left(\mathrm{c}=0.15 \mathrm{~mol} \mathrm{dm}^{-3}\right)$ for $120 \mathrm{~s}$. The signal was evaluated on the basis of Fraunhofer diffraction. The measurement is performed in three steps, results are automatically calculated as average and presented as $d_{10}, d_{50}, d_{90}$ values.

\section{Results and discussion}

Thermal analysis

Thermal behaviour of reaction mixtures containing $\mathrm{SnO}_{2}, \mathrm{Co}(\mathrm{OH})_{2}, \mathrm{NH}_{4} \mathrm{H}_{2} \mathrm{PO}_{4}$ (eventually $\mathrm{Tb}_{4} \mathrm{O}_{7}$ ) was followed by methods of thermal analysis.

The TG and DTA curves of compound $\mathrm{Sn}_{0.760} \mathrm{Co}_{0.08} \mathrm{P}_{0.16} \mathrm{O}_{2}$ (mass sample $367.70 \mathrm{mg}$ ) are shown in Fig.1. The DTA curve shows the three endothermic effects and one exothermic effect. The first endothermic peak with the minimum at $110{ }^{\circ} \mathrm{C}$ is attributed to the loss of physisorbed water. The sharp and strong endothermic peak with the minimum at $230{ }^{\circ} \mathrm{C}$ is connected melting process and decomposition of $\mathrm{NH}_{4} \mathrm{H}_{2} \mathrm{PO}_{4}$. The melting and decomposition processes are very close to each other. The ammonium dihydrogen phosphate decomposed to orthophosphoric acid $\mathrm{H}_{3} \mathrm{PO}_{4}$, with the evolution of ammonia. The small amounts of $\left(\mathrm{NH}_{4}\right)_{2} \mathrm{H}_{2} \mathrm{P}_{2} \mathrm{O}_{7}$ and $\mathrm{H}_{4} \mathrm{P}_{2} \mathrm{O}_{7}$ were probably also formed. Then in the temperature range $230-400{ }^{\circ} \mathrm{C}$ the orthophosphoric acid is transformed to pyrophosphoric acid $\mathrm{H}_{4} \mathrm{P}_{2} \mathrm{O}_{7}$. The pyrophosphoric acid is liquid in this temperature range $\left(T_{m}=61{ }^{\circ} \mathrm{C}\right)$ and the subsequent heating of the sample led to the dehydration of $\mathrm{H}_{4} \mathrm{P}_{2} \mathrm{O}_{7}$, which was transformed to metaphosphoric acid $\mathrm{HPO}_{3}$. At the same time, this heating process resulted in polycondensation reaction and formation of the polyphosphate acids. The TG data show a continuous weight loss up in the temperature range $230-780^{\circ} \mathrm{C}$ without any constant segment, indicating that the above reactions take place continuously in a very complex manner, and cannot be separated as individual reactions [26-29]. The third endothermic peak at $280{ }^{\circ} \mathrm{C}$ is connected with the formation of $\mathrm{Co}_{3} \mathrm{O}_{4}$ [30-31]. The minor exothermic peaks with the maximum at 507, 615 and $732{ }^{\circ} \mathrm{C}$ could be related with the decomposition of $\left(\mathrm{NH}_{4}\right)_{2} \mathrm{H}_{2} \mathrm{P}_{2} \mathrm{O}_{7}$ and $\mathrm{HPO}_{3}$ to $\mathrm{P}_{2} \mathrm{O}_{5}$ and with the reaction of phosphorus compound with $\mathrm{SnO}_{2}$ and subsequent incorporation of $\mathrm{P}(\mathrm{V})$ ions into the lattice of $\mathrm{SnO}_{2}$ as well [32]. The exothermic peak with the maximum at $1055^{\circ} \mathrm{C}$ is probably connected with the start of formation of $\mathrm{Co}_{3}\left(\mathrm{PO}_{4}\right)_{2}$ structure. The total mass loss which is showed on TG curve was $7.24 \%$. It is mainly caused by thermal decomposition of cobalt and phosphorous compounds and elimination of water in the temperature interval $220-780^{\circ} \mathrm{C}$. 


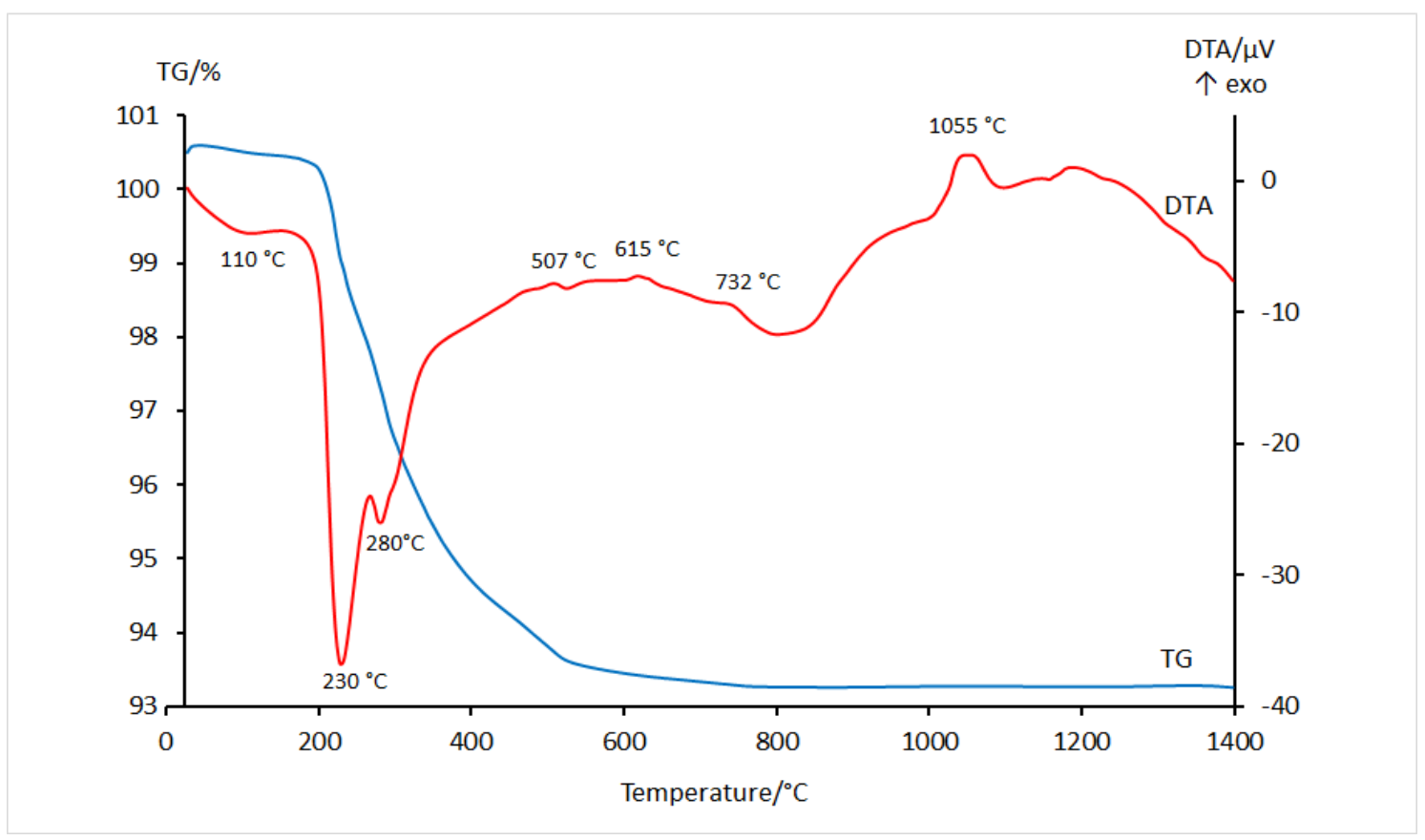

Fig. 1 The DTA/ TG curve of the reaction mixture containing $\mathrm{SnO}_{2}, \mathrm{Co}(\mathrm{OH})_{2}$ and $\mathrm{NH}_{4} \mathrm{H}_{2} \mathrm{PO}_{4}(367.70 \mathrm{mg})$

Table 1 Thermal decomposition of reaction mixture containing Sn, Co, P precursors for preparation of $\mathrm{Sn}_{0.760} \mathrm{Co}_{0.008} \mathrm{P}_{0.16} \mathrm{O}_{2}$

\begin{tabular}{ccc}
\hline Temperature range $/{ }^{\circ} \mathbf{C}$ & Peak temperature $/{ }^{\circ} \mathbf{C}$ & Mass change $/ \%$ \\
\hline $30-230$ & 110,230 (endo) & -1.59 \\
$230-400$ & 280 (endo) & -4.24 \\
$400-770$ & $507,615,732$ (exo) & -1.40 \\
$770-1400$ & 1055 (exo) & -0.01 \\
\hline
\end{tabular}

Figure 2 describes the thermal behaviour of the reaction mixture for preparation of sample $\mathrm{Sn}_{0.752} \mathrm{Co}_{0.08} \mathrm{P}_{0.16} \mathrm{~Tb}_{0.008} \mathrm{O}_{2}$ (mass sample $320.01 \mathrm{mg}$ ). The endothermic peaks in the temperature range $99-228{ }^{\circ} \mathrm{C}$ are connected with the loss of physisorbed and chemically bound water. The next endothermic peak with the minimum at temperature $273{ }^{\circ} \mathrm{C}$ corresponds with the formation of $\mathrm{Co}_{3} \mathrm{O}_{4}$. The exothermic peaks with maximum the at 464,616 and $754{ }^{\circ} \mathrm{C}$ (as in the case of $\mathrm{Sn}_{0.760} \mathrm{Co}_{0.08} \mathrm{P}_{0.16} \mathrm{O}_{2}$ ) could be related to the reaction of phosphorus compound with $\mathrm{SnO}_{2}$ and with the incorporation of $\mathrm{P}(\mathrm{V})$ ions into the lattice of $\mathrm{SnO}_{2}$. The terbium ions were available in two oxidation states in the raw material mixed oxide $\mathrm{Tb}_{4} \mathrm{O}_{7}\left(\mathrm{~Tb}_{2} \mathrm{O}_{3} \cdot \mathrm{TbO}_{2}\right)$. During the heat treatment, this mixed oxide changes to $\mathrm{Tb}_{2} \mathrm{O}_{3}$ at the temperature about $950{ }^{\circ} \mathrm{C}$ and the temperature above $1400{ }^{\circ} \mathrm{C}$ occurs to the oxidation of $\mathrm{Tb}$ (III) ions to the $\mathrm{Tb}$ (IV) ions [33]. These effects were not detected on the DTA-TG curve perhaps because the mixed oxide $\mathrm{Tb}_{4} \mathrm{O}_{7}$ was used in the very low quantities. The endothermic peak with the minimum at $1142{ }^{\circ} \mathrm{C}$ corresponds to the phase transformation from $\mathrm{TbPO}_{4}$ (monoclinic) to $\mathrm{TbPO}_{4}$ (tetragonal) [34]. The exothermic peak with the maximum at $1248{ }^{\circ} \mathrm{C}$ is connected with the start of formation of final structure. The total mass loss which is showed on TG curve was $5.58 \%$ and it is mainly caused by thermal decomposition of cobalt and phosphorous compounds and elimination of water in the temperature interval $220-760{ }^{\circ} \mathrm{C}$.

On the basis of results of thermal analysis, the reaction mixture containing rare earth oxides were calcinated in the temperature range $1350-1550{ }^{\circ} \mathrm{C}$. 


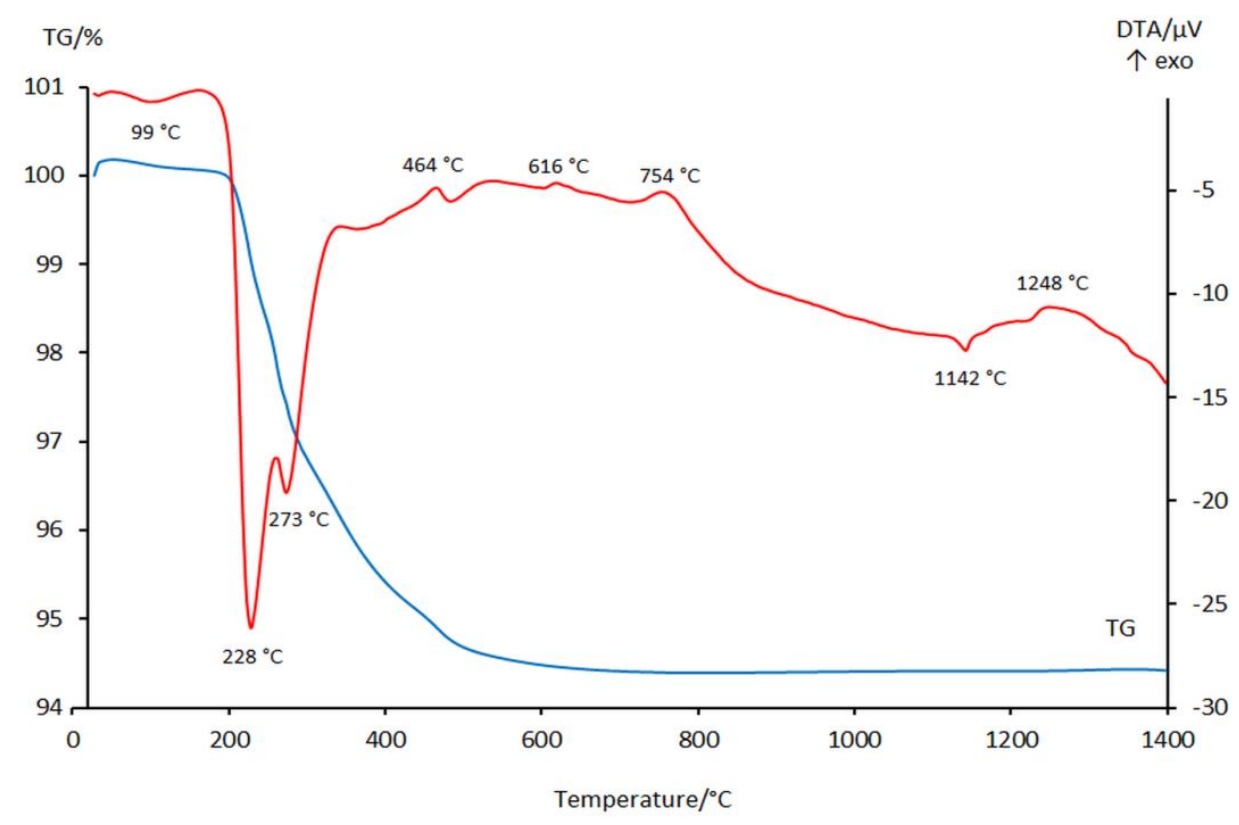

Fig. 2 The DTA/ TG curve of the reaction mixture containing $\mathrm{SnO}_{2}, \mathrm{Co}(\mathrm{OH})_{2}, \mathrm{NH}_{4} \mathrm{H}_{2} \mathrm{PO}_{4}$ and $\mathrm{Tb}_{4} \mathrm{O}_{7}$ (320.01 mg)

Table 2 Thermal decomposition of reaction mixture containing $\mathrm{Sn}, \mathrm{Co}, \mathrm{P}$ and $\mathrm{Tb}$ precursors for preparation of $\mathrm{Sn}_{0.752} \mathrm{Co}_{0.08} \mathrm{P}_{0.16} \mathrm{~Tb}_{0.008} \mathrm{O}_{2}$

\begin{tabular}{ccc}
\hline Temperature range $/{ }^{\circ} \mathbf{C}$ & Peak temperature $/{ }^{\circ} \mathbf{C}$ & Mass change $/ \%$ \\
\hline $30-233$ & 99,228 (endo) & -1.15 \\
$233-403$ & 273 (endo) & -3.46 \\
$403-773$ & $464,616,754($ exo $)$ & -1.00 \\
$773-1398$ & $1142($ endo), 1248(exo) & +0.03 \\
\hline
\end{tabular}

XRD analysis

The powder pigments were studied by XRD analysis. The diffractograms of the samples were singlephased at higher synthesis temperatures. Due to results of thermal analysis the analysis of the phase composition of the reaction mixture fired at $900{ }^{\circ} \mathrm{C}, 1100^{\circ} \mathrm{C}$ and $1200{ }^{\circ} \mathrm{C}$ was also performed (Table 3). The secondary phase, corresponded with monoclinic structure of $\mathrm{Co}_{2} \mathrm{P}_{2} \mathrm{O}_{7}$ was observed at all samples, which were prepared in the temperature range $900-1200{ }^{\circ} \mathrm{C}$. The sample of $\mathrm{Sn}_{0.760} \mathrm{Co}_{0.08} \mathrm{P}_{0.16} \mathrm{O}_{2}$ provided tertiary crystalline phase corresponding with monoclinic $\mathrm{Co}_{3}\left(\mathrm{PO}_{4}\right)_{2}$ in the temperature range $1100-1200{ }^{\circ} \mathrm{C}$ and the sample of $\mathrm{Sn}_{0.752} \mathrm{Co}_{0.08} \mathrm{P}_{0.16} \mathrm{~Tb}_{0.008} \mathrm{O}_{2}$ provided tertiary crystalline phase corresponding with $\mathrm{TbPO}_{4}$ in the temperature range $900-1200{ }^{\circ} \mathrm{C}$, when the phase transformation from monoclinic $\mathrm{TbPO}_{4}$ to tetragonal $\mathrm{TbPO}_{4}$ occurred at $1142{ }^{\circ} \mathrm{C}$.

At prepared pigments, the only major crystalline phase corresponding to tetragonal cassiterite structure of $\mathrm{SnO}_{2}$ with $\mathrm{P}_{2} / \mathrm{mnm}$ symmetry (JPDF No. 04-003-0649), was confirmed. No other phases were detected in the XRD patterns. The intensities of peaks increased with calcination temperature, which meant that the peaks were the sharpest and the most intense at $1450{ }^{\circ} \mathrm{C}$. The intensity of $\mathrm{Sn}_{0.752} \mathrm{Co}_{0.08} \mathrm{P}_{0.16} \mathrm{~Tb}_{0.008} \mathrm{O}_{2}$ pigment rapidly decreased at $1500^{\circ} \mathrm{C}$ (Fig. 3) however the intensity of $\mathrm{Sn}_{0.760} \mathrm{Co}_{0.08} \mathrm{P}_{0.16} \mathrm{O}_{2}$ remained the same at this calcination temperature (Fig. 4). The XRD analysis confirmed that the synthesis temperature of $1350{ }^{\circ} \mathrm{C}$ is sufficient to get a single-phase compound (Table 4). The contraction of lattice constants confirmed the incorporation of $\mathrm{Co}$ and $\mathrm{Tb}$ ions in $\mathrm{SnO}_{2}$ host lattice. 
Table 3 Characterization of the crystal structure of the samples prepared at calcination temperature 900,1100 and $1200{ }^{\circ} \mathrm{C}$

\begin{tabular}{|c|c|c|c|}
\hline Pigment & Temperature $/{ }^{\circ} \mathrm{C}$ & Obtained phases & JPDF card number \\
\hline \multirow{9}{*}{$\mathrm{Sn}_{0.760} \mathrm{Co}_{0.08} \mathrm{P}_{0.16} \mathrm{O}_{2}$} & \multirow{3}{*}{900} & $\mathrm{SnO}_{2}$ (tetragonal) & 01-071-0652 \\
\hline & & $\mathrm{Co}_{2} \mathrm{P}_{2} \mathrm{O}_{7}$ (monoclinic) & 01-070-1491 \\
\hline & & Unknown & - \\
\hline & \multirow{3}{*}{1100} & $\mathrm{SnO}_{2}$ (tetragonal) & $01-071-0652$ \\
\hline & & $\mathrm{Co}_{2} \mathrm{P}_{2} \mathrm{O}_{7}$ (monoclinic) & 01-070-1491 \\
\hline & & $\mathrm{Co}_{3}\left(\mathrm{PO}_{4}\right)_{2}$ (monoclinic) & 01-070-1795 \\
\hline & \multirow{3}{*}{1200} & $\mathrm{SnO}_{2}$ (tetragonal) & $01-071-0652$ \\
\hline & & $\mathrm{Co}_{2} \mathrm{P}_{2} \mathrm{O}_{7}$ (monoclinic) & $01-070-1491$ \\
\hline & & $\mathrm{Co}_{3}\left(\mathrm{PO}_{4}\right)_{2}$ (monoclinic) & 01-070-1795 \\
\hline \multirow{9}{*}{$\mathrm{Sn}_{0.752} \mathrm{Co}_{0.08} \mathrm{P}_{0.16} \mathrm{~Tb}_{0.008} \mathrm{O}_{2}$} & \multirow{3}{*}{900} & $\mathrm{SnO}_{2}$ (tetragonal) & 01-071-0652 \\
\hline & & $\mathrm{Co}_{2} \mathrm{P}_{2} \mathrm{O}_{7}$ (monoclinic) & 01-070-1491 \\
\hline & & $\mathrm{TbPO}_{4}$ (monoclinic) & 01-077-0224 \\
\hline & \multirow{3}{*}{1100} & $\mathrm{SnO}_{2}$ (tetragonal) & $01-071-0652$ \\
\hline & & $\mathrm{Co}_{2} \mathrm{P}_{2} \mathrm{O}_{7}$ (monoclinic) & 01-070-1491 \\
\hline & & $\mathrm{TbPO}_{4}$ (monoclinic) & $01-077-0224$ \\
\hline & \multirow{3}{*}{1200} & $\mathrm{SnO}_{2}$ (tetragonal) & $01-071-0652$ \\
\hline & & $\mathrm{Co}_{2} \mathrm{P}_{2} \mathrm{O}_{7}$ (monoclinic) & 01-070-1491 \\
\hline & & $\mathrm{TbPO}_{4}$ (tetragonal) & 01-079-6618 \\
\hline
\end{tabular}

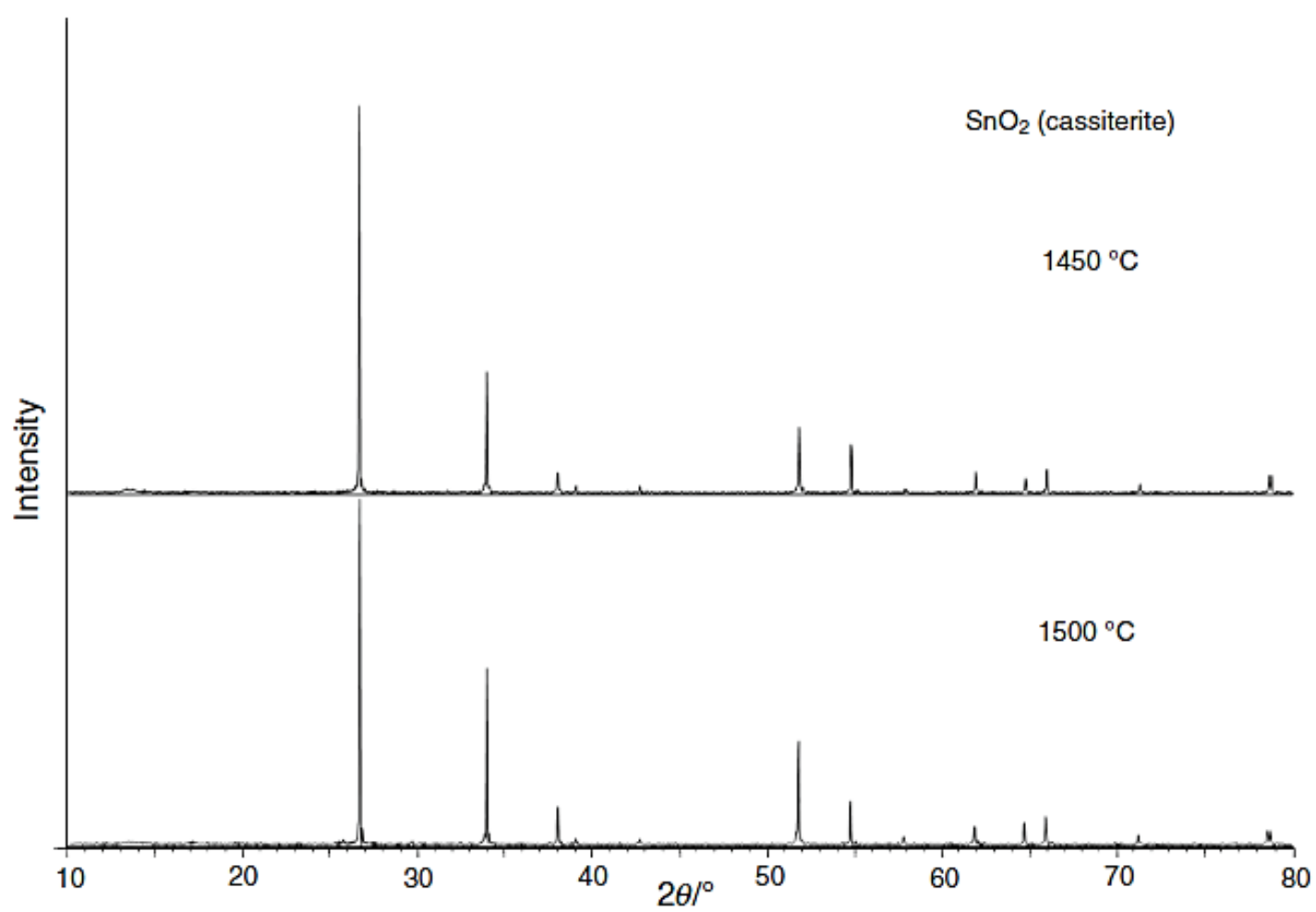

Fig. $3 \mathrm{X}$-ray diffraction patterns of $\mathrm{Sn}_{0.752} \mathrm{Co}_{0.08} \mathrm{P}_{0.16} \mathrm{~Tb}_{0.008} \mathrm{O}_{2}$ synthesized at calcination temperature $1450{ }^{\circ} \mathrm{C}$ and $1500^{\circ} \mathrm{C}$. 
Table 4 Characterization of the crystal structure of the prepared pigments

\begin{tabular}{ccccc}
\hline Pigment & Temperature $/{ }^{\circ} \mathbf{C}$ & Obtained phases & $\boldsymbol{a} / \mathbf{n m}$ & $\boldsymbol{c} / \mathbf{n m}$ \\
\hline & 1350 & & 0.473662 & 0.318631 \\
& 1400 & $\mathrm{SnO}_{2}$ & 0.473674 & 0.318639 \\
$\mathrm{Sn}_{0.760} \mathrm{Co}_{0.08} \mathrm{P}_{0.16} \mathrm{O}_{2}$ & 1450 & tetragonal & 0.473694 & 0.318645 \\
& 1500 & & 0.473700 & 0.318550 \\
& 1350 & & 0.473595 & 0.318629 \\
& 1400 & $\mathrm{SnO}_{2}$ & 0.473675 & 0.318638 \\
$\mathrm{Sn}_{0.752} \mathrm{Co}_{0.08} \mathrm{P}_{0.16} \mathrm{~Tb}_{0.008} \mathrm{O}_{2}$ & 1450 & tetragonal & 0.473763 & 0.318696 \\
& 1500 & & 0.473776 & 0.318686 \\
\hline
\end{tabular}

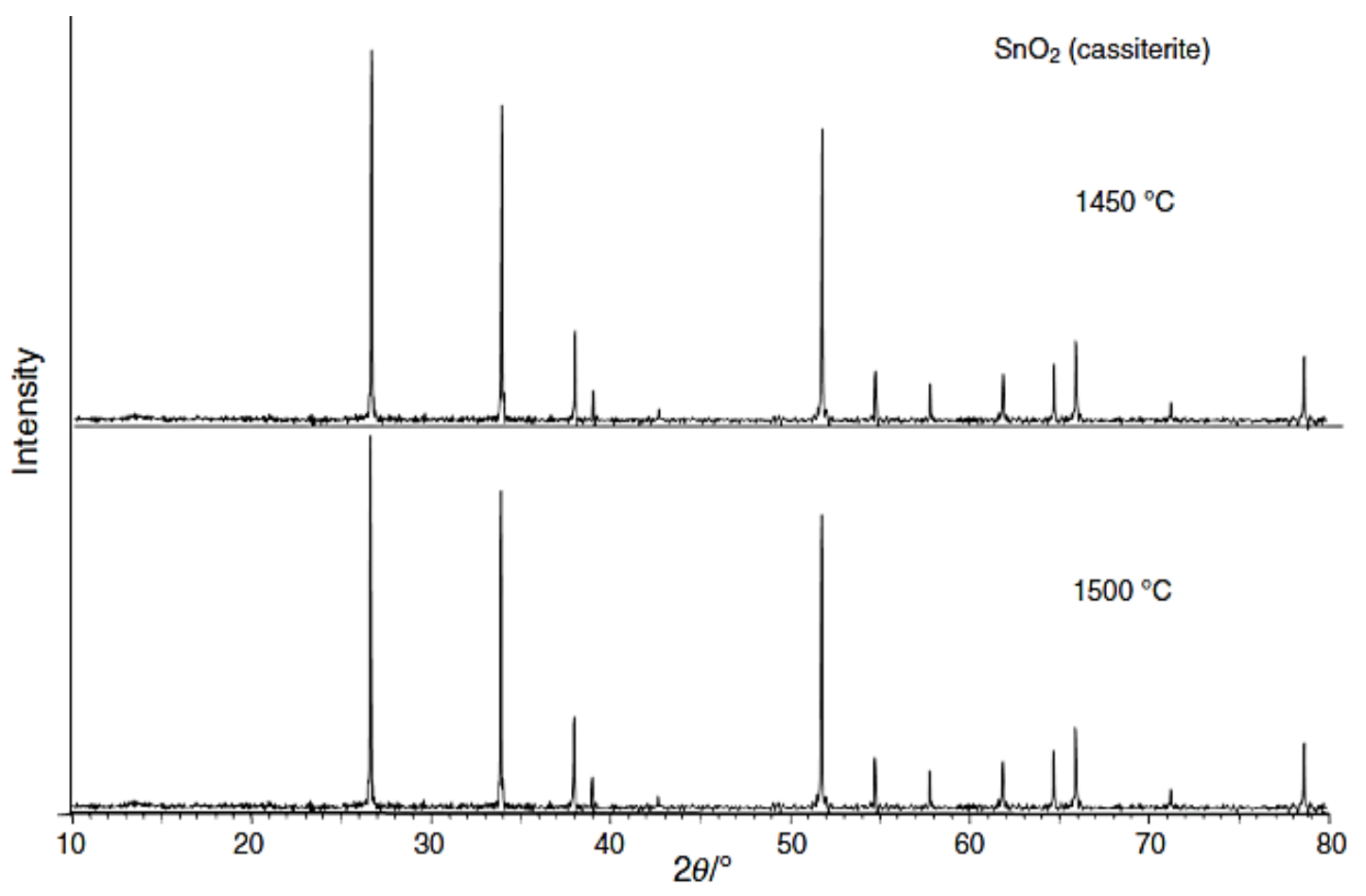

Fig. $4 \mathrm{X}$-ray diffraction patterns of $\mathrm{Sn}_{0.760} \mathrm{Co}_{0.08} \mathrm{P}_{0.16} \mathrm{O}_{2}$ synthesized at calcination temperature $1450{ }^{\circ} \mathrm{C}$ and $1500{ }^{\circ} \mathrm{C}$.

Colour properties

Currently, the lack of violet pigments shades is on the market. Therefore, the effect of terbium ions on the colour properties of $\mathrm{Sn}_{0.760} \mathrm{Co}_{0.08} \mathrm{P}_{0.16} \mathrm{O}_{2}$ was investigated. The aim of the research was to intensify red shade in the final colouration of prepared pigments and to obtain violet or blue violet colour.

The effect of growing calcination temperature and the effect of terbium ions on colour properties of the cassiterite pigments were investigated. At first, the prepared powder materials were applied into the organic matrix in mass tone. From Tab. 5 and Tab. 6 it is evident that the values of colour coordinates $a^{*}, b^{*}$ and value $C$ (chroma) subsequently increase with ascending temperature of calcination. On the other hand the values of coordinates $L^{*}$ (lightness) decline. All pigments produce blue-violet hue. This fact is obvious in view of the value $H^{\circ}$, which lies in range of $294.74^{\circ}$ to $307.31^{\circ}$. The admixture of terbium ions a positive effect on colour properties. The comparison of synthesised pigments $\mathrm{Sn}_{0.760} \mathrm{Co}_{0.08} \mathrm{P}_{0.16} \mathrm{O}_{2}$ and $\mathrm{Sn}_{0.752} \mathrm{Co}_{0.08} \mathrm{P}_{0.16} \mathrm{~Tb}_{0.008} \mathrm{O}_{2}$ in terms of acquired colour properties showed that pigments with terbium ions provide lower values of lightness $L^{*}$. Furthermore, pigments doped by terbium ions provide the increase of chroma $C$. All of the prepared terbium doped pigments have higher values of both colour coordinates $\left(+a^{*},-b^{*}\right)$. This fact is also confirmed by mostly increasing values of angle $H^{\circ}$. It means that $\mathrm{Sn}_{0.752} \mathrm{Co}_{0.08} \mathrm{P}_{0.16} \mathrm{~Tb}_{0.008} \mathrm{O}_{2}$ pigments in comparison with $\mathrm{Sn}_{0.760} \mathrm{Co}_{0.08} \mathrm{P}_{0.16} \mathrm{O}_{2}$ are shifted closer toward blue-violet 
shades. The best results are obtained with ions of terbium as admixture at the firing temperature $1450{ }^{\circ} \mathrm{C}$. In this case, the sample acquires the highest value of colour coordinate $a^{*}(22.02)$, the highest value of chroma (36.33) and the highest value of hue angle $\left(307.31^{\circ}\right)$. This sample is characterised by violet colour. The values of total colour difference describe colour differences between samples $\left(\mathrm{Sn}_{0.752} \mathrm{Co}_{0.08} \mathrm{P}_{0.16} \mathrm{~Tb}_{0.008} \mathrm{O}_{2}\right)$ and standard $\left(\mathrm{Sn}_{0.760} \mathrm{Co}_{0.08} \mathrm{P}_{0.16} \mathrm{O}_{2}\right)$. The pigment synthesised at $1450{ }^{\circ} \mathrm{C}$ disposes of the highest value of the total colour difference (25.81). It is mainly caused by the decrease of lightness and increase of coordinate $+a^{*}$.

Table 5 CIE $L^{*} a^{*} b^{*}$ parameters of $\mathrm{Sn}_{0.760} \mathrm{Co}_{0.008} \mathrm{P}_{0.16} \mathrm{O}_{2}$ powders applied into the organic matrix

\begin{tabular}{cccccc}
\hline $\mathbf{T} /{ }^{\circ} \mathbf{C}$ & $\mathbf{L}^{*}$ & $\mathbf{a}^{*}$ & $\mathbf{b}^{*}$ & $\mathbf{C}$ & $\mathbf{H}^{\circ}$ \\
\hline 1350 & 56.19 & 7.86 & -15.31 & 17.21 & 297.18 \\
1400 & 56.99 & 4.64 & -10.07 & 11.09 & 294.74 \\
1450 & 59.16 & 6.78 & -13.27 & 14.90 & 297.06 \\
1500 & 45.38 & 9.11 & -24.36 & 26.00 & 290.50 \\
\hline
\end{tabular}

Table 6 CIE $L * a * b *$ parameters of $\mathrm{Sn}_{0.752} \mathrm{Co}_{0.08} \mathrm{P}_{0.16} \mathrm{~Tb}_{0.008} \mathrm{O}_{2}$ powders applied into the organic matrix

\begin{tabular}{ccccccc}
\hline $\mathbf{T} /{ }^{\circ} \mathbf{C}$ & $\mathbf{L}^{*}$ & $\mathbf{a}^{*}$ & $\mathbf{b}^{*}$ & $\mathbf{C}$ & $\mathbf{H}^{\circ}$ & $\mathbf{\Delta E}^{*} \mathbf{C I E}$ \\
\hline 1350 & 61.55 & 6.07 & -11.72 & 13.20 & 297.38 & 5.06 \\
1400 & 58.31 & 8.23 & -14.78 & 16.92 & 299.11 & 2.22 \\
1450 & 45.37 & 22.02 & -28.89 & 36.33 & 307.31 & 25.81 \\
1500 & 54.86 & 12.98 & -18.22 & 22.37 & 305.47 & 5.63 \\
\hline
\end{tabular}

The second system was pigment applied into the transparent ceramic glaze with glazing temperature 1050 ${ }^{\circ} \mathrm{C}$. The tested cassiterite pigments belong to the group of the high-temperature pigments, and therefore the glaze with the middle temperature of glazing for the study of colour properties was selected. The colour properties of synthesised pigments applied into transparent ceramic glaze are showed in Tab. 7 and Tab. 8. In the case of the $\mathrm{Sn}_{0.752} \mathrm{Co}_{0.08} \mathrm{P}_{0.16} \mathrm{~Tb}_{0.008} \mathrm{O}_{2}$ pigments, growing synthesis temperature causes a drop of value $L^{*}$ (approx. from 47 to 40). For these types of pigments, rising temperature caused the slight increase of the chroma $C$. However the blue colour has a bigger impact on the increasing of $C$ and values of $a^{*}$ increase with temperature. On the other hand, the red shade shows the insignificant increase. The values of coordinate $a^{*}$ ranged between 7 to 10 and coordinate $b^{*}$ reached values from -23 to -28 . This trend is apparent also from slight increasing values of angle $H^{\circ}$ within a very narrow range (approx. from $287^{\circ}$ to $290^{\circ}$ ) and these pigments provide blue-violet colour shades. The good results are obtained with ions of terbium as admixture at the firing temperature $1500{ }^{\circ} \mathrm{C}$. In this case, the highest value of the colour coordinate $a^{*}(9.95)$ and also the highest value of chroma (28.97) is achieved. The comparison of synthesised pigments $\mathrm{Sn}_{0.760} \mathrm{Co}_{0.08} \mathrm{P}_{0.16} \mathrm{O}_{2}$ and $\mathrm{Sn}_{0.752} \mathrm{Co}_{0.08} \mathrm{P}_{0.16} \mathrm{~Tb}_{0.008} \mathrm{O}_{2}$ in terms of acquired colour properties demonstrates that pigments with ions of terbium provided lower values of lightness $L^{*}$ from the temperature of $1450{ }^{\circ} \mathrm{C}$. The chroma (in comparison with $\mathrm{Sn}_{0.76} \mathrm{Co}_{0.08} \mathrm{P}_{0.16} \mathrm{O}_{2}$ pigments) decreases at $1400{ }^{\circ} \mathrm{C}$ from approx. 28 to 24 and subsequently grows from approx. 24 to 30, when firing temperature increases. The highest effect on the increase of chroma $C$ at $1500{ }^{\circ} \mathrm{C}$ has a distinct increase of value $b^{*}$ compared with standard pigments $\operatorname{Sn}_{0.760} \mathrm{Co}_{0.08} \mathrm{P}_{0.16} \mathrm{O}_{2}$. The values of total colour difference are low for samples synthesised in temperature range of $1350-1400{ }^{\circ} \mathrm{C}$. It means that colour differences $\triangle E^{*}{ }_{C I E}$ between standard $\left(\mathrm{Sn}_{0.760} \mathrm{Co}_{0.08} \mathrm{P}_{0.16} \mathrm{O}_{2}\right)$ and samples $\left(\mathrm{Sn}_{0.752} \mathrm{Co}_{0.08} \mathrm{P}_{0.16} \mathrm{~Tb}_{0.008} \mathrm{O}_{2}\right)$ are imperceptible to the human eye. The highest value of total colour difference $\Delta E^{*} C I E$ (5.77) is observed in case of pigment synthesised at $1500^{\circ} \mathrm{C}$. This fact is mainly caused by the decrease of lightness and increase of coordinate $-b^{*}$.

In this case, the best results provided pigments synthesised at higher calcination temperatures (1450 and $1500{ }^{\circ} \mathrm{C}$ ). At calcination temperature $1450{ }^{\circ} \mathrm{C}$, great results were obtained thanks to the high intensity of crystalline phase as well. The prepared $\mathrm{Sn}_{0.752} \mathrm{Co}_{0.08} \mathrm{P}_{0.16} \mathrm{~Tb}_{0.008} \mathrm{O}_{2}$ pigments provided in both applications (organic matrix, ceramic glaze) required blue or blue-violet colouration.

Table 7 CIE $L * a * b *$ parameters of $\mathrm{Sn}_{0.760} \mathrm{Co}_{0.008} \mathrm{P}_{0.16} \mathrm{O}_{2}$ powders applied into the ceramic glaze $\mathrm{P} 07491$

\begin{tabular}{cccccc}
\hline $\mathbf{T} /{ }^{\circ} \mathbf{C}$ & $\mathbf{L}^{*}$ & $\mathbf{a}^{*}$ & $\mathbf{b}^{*}$ & $\mathbf{C}$ & $\mathbf{H}^{\circ}$ \\
\hline 1350 & 46.59 & 8.13 & -25.20 & 26.48 & 287.88 \\
1400 & 45.75 & 8.81 & -26.58 & 28.00 & 288.34
\end{tabular}


Table $8 \mathrm{CIE} L^{*} a^{*} b^{*}$ parameters of $\mathrm{Sn}_{0.752} \mathrm{Co}_{0.08} \mathrm{P}_{0.16} \mathrm{~Tb}_{0.008} \mathrm{O}_{2}$ powders applied into the ceramic glaze $\mathrm{P} 07491$

\begin{tabular}{ccccccc}
\hline $\mathbf{T} /{ }^{\circ} \mathbf{C}$ & $\mathbf{L}^{*}$ & $\mathbf{a}^{*}$ & $\mathbf{b}^{*}$ & $\mathbf{C}$ & $\mathbf{H}^{\circ}$ & $\mathbf{\Delta E}^{*} \mathbf{C I E}$ \\
\hline 1350 & 46.54 & 7.44 & -23.44 & 24.59 & 287.61 & 0.69 \\
1400 & 46.61 & 8.01 & -25.33 & 26.57 & 287.55 & 1.17 \\
1450 & 43.65 & 9.15 & -26.82 & 28.34 & 288.84 & 3.82 \\
1500 & 40.43 & 9.95 & -27.21 & 28.97 & 290.09 & 5.77 \\
\hline
\end{tabular}

The Kubelka-Munk absorption spectra of samples $\mathrm{Sn}_{0.760} \mathrm{Co}_{0.08} \mathrm{P}_{0.16} \mathrm{O}_{2}$ and $\mathrm{Sn}_{0.752} \mathrm{Co}_{0.08} \mathrm{P}_{0.16} \mathrm{~Tb}_{0.008} \mathrm{O}_{2}$ shown on Fig. 5 present the characteristic spectrum of Co (II) ion in tetrahedral coordination [35], with a triple absorption peak centred in the visible region of light at approximately $560 \mathrm{~nm}$ (green region), $580 \mathrm{~nm}$ (yelloworange region) and $610 \mathrm{~nm}$ (red region), and with a multiple reflection valley between 400-450 nm (blue region), which gives rise to the blue-violet colour.

Substitution of part $\mathrm{Sn}^{4+}$ ions by terbium ions in pigment $\mathrm{Sn}_{0.752} \mathrm{Co}_{0.08} \mathrm{P}_{0.16} \mathrm{~Tb}_{0.008} \mathrm{O}_{2}$ caused origin of significant absorption band centred at $490 \mathrm{~nm}$. The absorption edge of this sample is shift from $625 \mathrm{~nm}$ $\mathrm{Sn}_{0.760} \mathrm{Co}_{0.08} \mathrm{P}_{0.16} \mathrm{O}_{2}$ to $650 \mathrm{~nm}$.

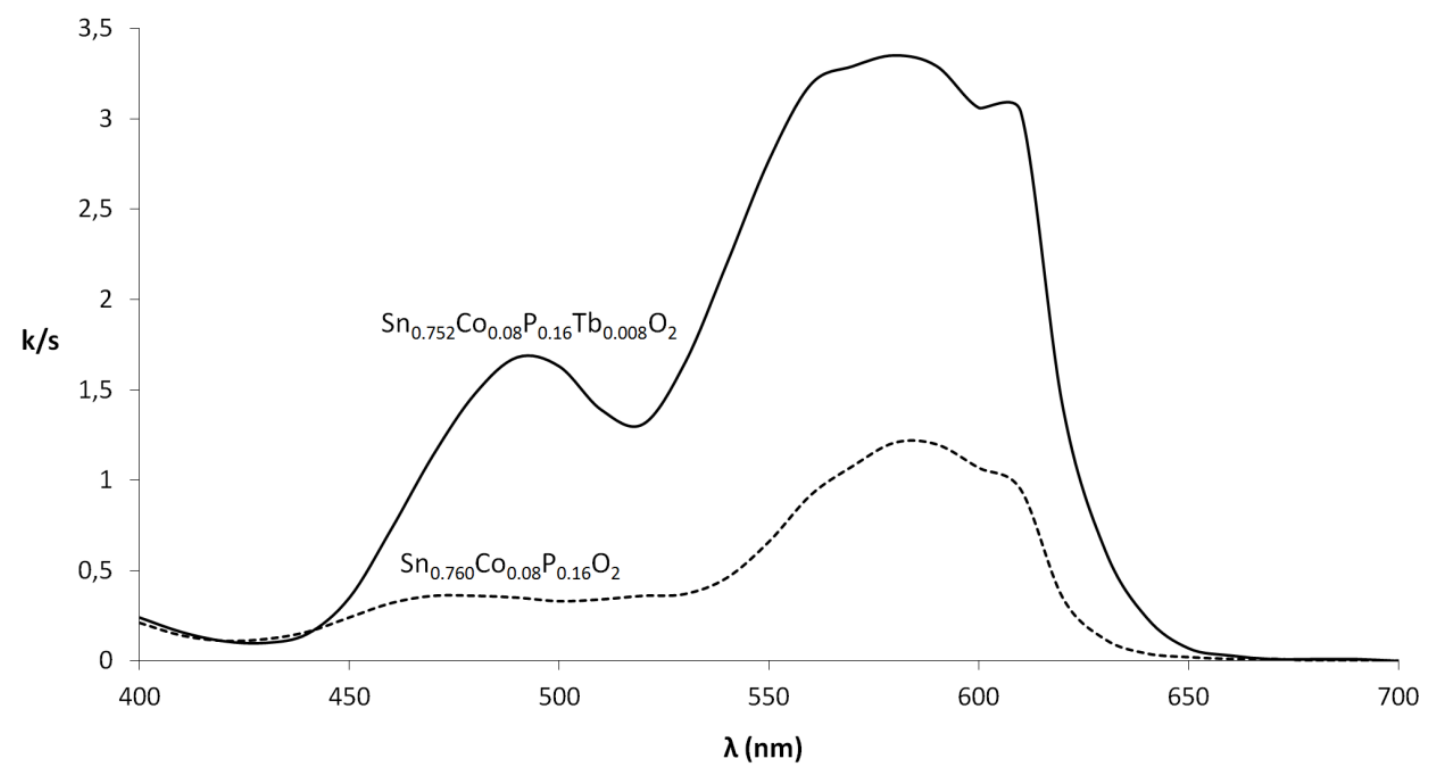

Fig. 5 Kubelka-Munk absorbtion spectra of $\mathrm{Sn}_{0.760} \mathrm{Co}_{0.08} \mathrm{P}_{0.16} \mathrm{O}_{2}$ and $\mathrm{Sn}_{0.752} \mathrm{Co}_{0.08} \mathrm{P}_{0.16} \mathrm{~Tb}_{0.008} \mathrm{O}_{2}$ powders (synthesis temperature of $1450^{\circ} \mathrm{C}$ ) applied into the organic matrix

Particle size distribution

All prepared pigments were characterised by measuring of the particle size distribution. The most important value, which characterises particle size, is the value $\mathrm{d}_{50}$ (median). From Table 9 is evident, that with the increase of calcination temperature, the main particle size grows too. Terbium doped pigments are characterised by lower values of $d_{50}$ in comparison with the standard pigments. Their values lie in range of 6 to $14 \mu \mathrm{m}$. A suitable granulometric composition for application of pigments into ceramic glaze is about 5-15 $\mu \mathrm{m}$. These values were attained for all prepared pigments. For their potential use in painting coats, it would be necessary to decrease their size mechanically.

Table 9 Particle size distribution of the samples $\mathrm{Sn}_{0.760} \mathrm{Co}_{0.008} \mathrm{P}_{0.16} \mathrm{O}_{2}$ and $\mathrm{Sn}_{0.752} \mathrm{Co}_{0.08} \mathrm{P}_{0.16} \mathrm{~Tb}_{0.008} \mathrm{O}_{2}$ 


\begin{tabular}{ccccc}
\hline Sample & $\mathbf{T} /{ }^{\circ} \mathbf{C}$ & $\mathbf{d}_{\mathbf{1 0}} / \boldsymbol{\mu m}$ & $\mathbf{d}_{\mathbf{5 0}} / \boldsymbol{\mu m}$ & $\mathbf{d}_{\mathbf{9} \mathbf{m}} / \boldsymbol{\mu} \mathbf{m}$ \\
\hline & 1350 & 0.85 & 7.68 & 36.93 \\
& 1400 & 1.02 & 8.31 & 41.62 \\
$\mathrm{Sn}_{0.760} \mathrm{Co}_{0.08} \mathrm{P}_{0.16} \mathrm{O}_{2}$ & 1450 & 1.16 & 10.48 & 63.15 \\
& 1500 & 1.21 & 13.73 & 75.63 \\
\hline & 1350 & 0.90 & 6.44 & 40.06 \\
& 1400 & 0.88 & 6.87 & 38.17 \\
& 1450 & 0.83 & 7.05 & 43.86 \\
& 1500 & 1.03 & 9.04 & 59.61 \\
\hline
\end{tabular}

\section{Conclusions}

The main aim of the research was to prepare blue-violet $\mathrm{Sn}_{0.752} \mathrm{Co}_{0.08} \mathrm{P}_{0.16} \mathrm{~Tb}_{0.008} \mathrm{O}_{2}$ ceramic pigments. The samples were synthesised by classical ceramic method (solid state reaction). Methods of thermal analysis were used for assigning the optimal heating temperature necessary for the formation of a cassiterite structure. From the simultaneous TG-DTA analysis, it was found that the formation of the cassiterite compounds starts in the temperature range of $1250-1350{ }^{\circ} \mathrm{C}$. On the basis of results of thermal analysis, the calcination temperatures in the range of $1350-1500{ }^{\circ} \mathrm{C}$ were chosen. Studies of X-ray diffraction showed that single-phased samples were prepared in the temperature range of $1350-1500{ }^{\circ} \mathrm{C}$. The positive effect of the increasing synthesis temperature on the colour properties of pigments was found. From the obtained results it can be concluded, that higher calcination temperature generally stimulates the formation of darker powders with higher values of chroma $C$ and with higher values of hue angle $H^{\circ}$. According to the highest values of $C$ as a parameter characterising colour purity, the best temperature for synthesis of these pigments is $1450{ }^{\circ} \mathrm{C}$ for application into the organic matrix and $1500{ }^{\circ} \mathrm{C}$ for application into the ceramic glaze. The effect of terbium ions on pigmentary properties was also investigated. In comparison with $\mathrm{Sn}_{0.760} \mathrm{Co}_{0.008} \mathrm{P}_{0.16} \mathrm{O}_{2}$ pigments were obtained pigments with higher value of saturation and with the higher contribution of red and blue shade. The cassiterite pigments doped by ions of terbium provided violet shades in the organic matrix and blue-violet shades in the ceramic glaze. The median of particle size $d_{50}$ moved in range of $6.44-13.73 \mu \mathrm{m}$ in dependence on synthesis temperature (increasing character with increasing temperature), and this particle size is sufficient for the potential using in ceramic glazes.

\section{References}

[1] Buxbaum G., Pfaff G., Industrial Inorganic Pigments. $3^{\text {rd }}$ ed., Wiley-VCH, Verlag GmbH \& Co. KGaA, Weinheim, 2005.

[2] CPMA, Classification and chemical description of the complex inorganic color pigments, 4th ed. Alexandria,Virginia: Color Pigments Manufacturers Association, Inc., 2013:21-2.

[3] Mason RK. Use of cobalt colors in glazes. J Am Ceram Soc Bull. 1961;10:5.

[4] Monari G and Manfredini T, Coloring effects of synthetic inorganic cobalt pigments in fast-fired porcelainized tiles. J Ceram Eng Sci Proc. 1996;17:109.

[5] Paul A, Douglas RW. Optical absortion of divalent cobalt in binary alkali borate glasses and its relation to the basicity of glass. Phys Chem Glasses. 1968;9:139-49.

[6] Fagan JG, Amarakoon VRW. Reliability and reproducibility of ceramic sensors: part III, humidity sensors. Am Ceram Bull 1993;72:119.

[7] Subramanian V, Gnanasekar KI, Rambabu B. Nanocrystalline $\mathrm{SnO}_{2}$ and In-doped $\mathrm{SnO}_{2}$ as anode materials for lithium batteries. Solid State Ionics 2004;175:181.

[8] Feng G,Wang SF, Lu MK, Qi YX, Zhou GJ, Xu D, Yuan DR. Luminescent characteristics of Eu ${ }^{3+}$ in $\mathrm{SnO}_{2}$ nanoparticles. Opt Mater. 2004;59:25.

[9] Scott RWJ, Yang SM, Chabanis G, Coombs N, Williams DE, Ozin GA. Tin dioxide opals and inverted opals: near-ideal microstructures for gas sensors. Adv Mater. 2001;13:1468.

[10] Harrison PG, Bailey C, Azelee W. Modified tin (IV) oxide (M/SnO $2 \mathrm{M}=\mathrm{Cr}, \mathrm{La}, \mathrm{Pr}, \mathrm{Nd}, \mathrm{Sm}, \mathrm{Gd})$ catalysts for oxidation of carbon monooxide and propane. J Catal. 1999;186:147.

[11] Hudson K, Winbow H, Cowley J. Colors for ceramic bodies. Ceram Eng Sci Proc. 1996;17:102-10. 
[12] Tcheichvili L, Weyl WA. Synthesis of ceramic pigments. Glass Ind. 1963;11:208.

[13] Shannon RD. Revised effective ionic radii and systematic studies of interatomic distances in halides and chalcogenides. Acta Cryst. 1976;A32:751-67.

[14] Escribano P, Guillem MC, Guillem C. A study of the $\mathrm{SnO}_{2}-\mathrm{Cr}_{2} \mathrm{O}_{3}$ system. C Trans Brit Ceram Soc. 1983;82:208-10.

[15] Eppler ED and Eppler RA. The relative stability of ceramic pigments. Ceram Eng Sci Proc. 1997;18:13.

[16] Batzill M, Diebold U. The surface and material science of tin oxide. Prog Surf Sci. 2005;79:47-9.

[17] Beatriz J, Beltrán H, Cordoncillo E, Escribano P, Folgado JV, Vallet-Regí M, del Real RP. A study of the method of synthesis and chromatic properties of the $\mathrm{Cr}-\mathrm{SnO}_{2}$ pigment. Eur J Inor Chem. 2002;10:2694-2700.

[18] Fujiyoshi K, Yokoyama H. Chemical state of vanadium in tin-based yellow pigment. J Am Ceram Soc. 1993;76:981-6.

[19] Tena MA, Sorlí S, Llusar M, Badenes JA, Forés A, Monrós G. Study of Sb-doped $\mathrm{SnO}_{2}$ gray ceramic pigment with cassiterite structure. Z Anorg Alleg Chem 2005;631:2188-91.

[20] Varela JA, Cerri JA, Leite ER, Longo E,Shamsuzzoha M, Bradt RC. Microstrucural evolution during sintering of $\mathrm{CoO}$ doped $\mathrm{SnO}_{2}$ ceramics. Ceram Int. 1999;25:253-56.

[21] Sharma A, Singh AP, Thakur P, Brookes NB, Kumar S, Lee ChG, Choudhary RJ, Verma KD, Kumar R. Structural, electronic, and magnetic properties of Co doped $\mathrm{SnO}_{2}$ nanoparticles. J Appl Phys. 2010;107.

[22] Cerri JA, Gouvea D, Longo E,Varela JA. Effect of cobalt (II) oxide and manganese (IV)oxide on sintering of tin (IV) oxide. J Am Ceram Soc. 2005;79:799-804.

[23] Kim BC, Jung JI, Lee JH, Kim JJ. Precipitate concentration of $\mathrm{Co}_{2} \mathrm{SnO}_{4}$ in $\mathrm{CoO}$-doped $\mathrm{SnO}_{2}$ ceramics at different oxygen chemical potentials. Solid State Ionics. 2001;144:321-7.

[24] Mehraj S, Ansari MS, Alimuddin. Rutile-type Co doped $\mathrm{SnO}_{2}$ diluted magnetic semiconductor nanoparticles: Structural, dielectric and ferromagnetic behavior. Phys B. 2013;430:106-13.

[25] Fitzgerald CB, Venkatesan M, Douvalis AP, Huber S, Coey JMD, Bakas T. $\mathrm{SnO}_{2}$ doped with Mn, Fe or Co: room temperature in dilute magnetic semiconductors. J Appl Phys. 2014;95:7390-2.

[26] Gorodylova N, Šuclová P, Bosacka M, Filipek E. DTA-TG and XRD study on the reaction between $\mathrm{ZrOCl}_{2} .8$ $\mathrm{H}_{2} \mathrm{O}$ and $\left(\mathrm{NH}_{4}\right)_{2} \mathrm{HPO}_{4}$ for synthesis of $\mathrm{ZrP}_{2} \mathrm{O}_{7}$. J Therm Anal Calorim 2014;118:1095-1100.

[27] Zhang G, Peng Z, Li C. A study of thermal bahavior of cesium phosphate. J Therm Anal Calorim 2016;124:1063-70.

[28] Abdel-Kader A, Ammar AA,Saleh SI. Thermal behaviour of ammonium dihydrogen phosphate crystals in the temperature range $25-600^{\circ} \mathrm{C}$. Thermochim Acta 1991;176:293-304.

[29] Torijano E, Vargas RA, Diosa JE, Mellander BE. High temperature phase transition of $\mathrm{NH}_{4} \mathrm{H}_{2} \mathrm{PO}_{4}$. $\mathrm{Phys}_{\text {Stat }}$ Sol (B) 2000;220:659-62.

[30] Nicholls D. The chemistry of iron, cobalt and nickel: Comprehensive inorganic chemistry. Pergamon Press; 1973.

[31] Figlarz M, Guenot J, Tournemolle JN. Oxidation of cobalt (II) hydroxide to oxide hydroxide: solids evolution during reaction. J Mat Sci. 1974;9:772-6

[32] Shen Y, Nishida M, Kanematsu W, Hibino T. Synthesis and characterization of dense $\mathrm{SnP}_{2} \mathrm{O}_{7}-\mathrm{SnO}_{2}$ composite ceramics as intermediate temperature proton conductors. J Mater Chem 2011;21:663-670.

[33] Adachi G, Imanaka N. The binary rare earth oxides. Chem Rev. 1998;98:1479-1514.

[34] Yang M, You H, Song Y, Huang Y, Jia G, Liu K, Zheng Y, Zhang L, Zhang H. Synthesis and luminiscence properties of sheaflike $\mathrm{TbPO}_{4}$ hierarchical architectures with different phase structures. J Phys Chem 2009;113:20173-77.

[35] Khattab RM, Sadek HEH, Gaber AA. Synthesis of $\mathrm{Co}_{\mathrm{x}} \mathrm{Mg}_{1-\mathrm{x}} \mathrm{Al}_{2} \mathrm{O}_{4}$ nanospinel pigments by microwave combustion methods. Ceram Int 2017;43:234-43. 